D) Check for updates

Cite this as: $B M J 2021 ; 373: n 1174$ http://dx.doi.org/10.1136/bmj.n1174 Published: 07 May 2021

\section{Covid-19: Sputnik vaccine rockets, thanks to Lancet boost}

The provenance and peer review statement on this Essay (BMJ 2021;373:n1108, doi:) was incorrect. It has been updated to say that the article was externally peer reviewed. 